\title{
ESTIMATION OF STATURE FROM PERCUTANEOUS LENGTH OF ULNA
} IN LIVING SUBJECTS IN MARATHWADA REGION OF MAHARASHTRA

\section{Vaishali Inamdar ${ }^{1}$, Syed Imran Sultan *2.}

${ }^{1}$ Associate Professor, Department of Anatomy, Shankarrao Chavan Government Medical College Nanded, Maharashtra, India.

${ }^{*}$ Assistant Professor, Department of Anatomy, Shankarrao Chavan Government Medical College Nanded, Maharashtra, India.

\section{ABSTRACT}

Background: Estimation of stature plays an important role in medico-legal cases in the identification of unknown bodies, parts of bodies or even skeletal remains. There exists a strong relationship between stature and dimensions of different body parts, particularly bone lengths, which forms the basis for stature estimation. Ulna bone is used as it is subcutaneous and hence surface landmarks such as olecranon and styloid process are easily identifiable and can be used for measurements.

Materials and Methods: The present study was carried out on 300 medical students of Marathwada region of Dr. Shankarrao Chavan Government Medical College, Nanded, Maharashtra. Height and percutaneous ulna length were recorded for each subject.

Result: Mean height of male subjects is $171.99 \pm 6.04$. Mean of length of right and left ulna in male subjects are $26.92 \pm 1.30$ and $26.85 \pm 1.32$ respectively. The mean height of female subjects is $165.49 \pm 3.18$. Mean of length of right and left ulna in female subjects are $21.77 \pm 0.93$ and $21.69 \pm 0.88$ respectively. The correlation of stature with ulnar length is 0.66 in males and 0.70 in females, which are positive and statistically highly significant ( $P$ $<0.01$ ).

Conclusion: In Marathwada region of Maharashtra mean height and length of ulna is more in males than in females and it is statistically significant. Simple linear regression equation so far derived can be used if either of the measurement of length of ulna or total height is known, the other can be calculated. This fact will be of practical use in Medico Legal investigations and in Anthropometry.

KEY WORDS: Ulna Length, Height, Stature Estimation, Anthropometry, Marathwada Region

Address for Correspondence: Dr. Syed Imran Sultan, Department of Anatomy, Shankarrao Chavan Government Medical College Nanded, Maharashtra, India. E-Mail: drsyedimran86@gmail.com

\section{Quick Response code}

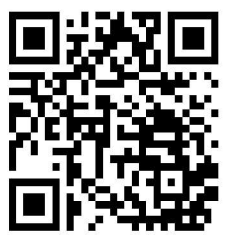

DOI: $10.16965 /$ ijar.2018.159 Journal Information

\begin{tabular}{|c|c|c|}
\hline \multicolumn{3}{|c|}{ Journal Information } \\
\hline \multicolumn{3}{|c|}{$\begin{array}{l}\text { International Journal of Anatomy and Research } \\
\begin{array}{l}\text { ICV for 2016 } \\
\text { ISSN (E) 2321-4287 | ISSN (P) 2321-8967 }\end{array}\end{array}$} \\
\hline \multicolumn{3}{|c|}{ Article Information } \\
\hline $\begin{array}{l}\text { Received: } 22 \text { Feb } 2018 \\
\text { Peer Review: } 22 \text { Feb } 2018 \\
\text { Revised: None }\end{array}$ & $\begin{array}{l}\text { Accepted: } 05 \mathrm{Apr} \\
\text { Published (O): } 05 \\
\text { Published (P): } 05\end{array}$ & $\begin{array}{l}8 \\
\text { y } 2018 \\
\text { y } 2018\end{array}$ \\
\hline
\end{tabular}

\section{INTRODUCTION}

Establishment of identity of unknown human remains is a challenging task in medico-legal cases, especially when the remains are partial, mutilated or dismembered. Such situations usually arise in cases of natural disasters, rail and aircraft accidents, wars and terrorist explosions. Many times, only parts of human body, such as limbs, are available for identification [1]. The height of an individual is one of the important parameters for establishing the identification [2]. Estimation of stature, therefore, plays an important role in medico-legal cases in the identification of unknown bodies, parts of bodies or even skeletal remains. There exists a strong relationship between stature and 
dimensions of different body parts, particularly bone lengths, which forms the basis for stature estimation [1].

The ulna is a long bone often used for body height estimation as it lies parallel in the forearm with their ends fairly superficially placed. The ulna is a long bone, prismatic in form, placed at the medial side of the forearm [3]. Ulna bone is used as it is subcutaneous and hence surface landmarks such as olecranon and styloid process are easily identifiable and can be used for measurements. ${ }^{2}$ Ossification of ulna begins at the 8th week of fetal life. The proximal epiphysis fuses with the shaft in 16th year and distal epiphysis with the shaft in 18th year in males [4].

\section{MATERIALS AND METHODS}

The present study was carried out on 300 medical students of Marathwada region of Dr. Shankarrao Chavan Government Medical College, Nanded, Maharashtra. Of the 300 subjects 150 were males and 150 females of age group 18-24 years. Height and percutaneous ulna length were recorded for each subject.

Height was measured by stature meter fixed to the wall. The height was measured without shoes bare feet. The subject was made to stand against the wall erect, arms hang loosely by the body and the heels, sacral region and the upper part of the back touching the wall.

Ulna length was measured with the subject sitting and forearm placed on the table flexed $90^{\circ}$ at the elbow. Length of ulna was measured as the straight distance between the most proximal point of the olecranon process to the most distal point of the styloid process in the supinated forearm [5].

Measurements were taken during fixed timings of the day between $1 \mathrm{pm}$ and $3 \mathrm{pm}$ to avoid diurnal variation. All measurements were taken by the same observer and with the same instrument to avoid any technical or inter-observer error and to maintain reproducibility. Both height and lengths of right and left ulna were measured separately and were noted in centimeters [5].

After collection of the data, they were subjected to statistical analysis. Mean, standard deviation, correlation coefficient, simple linear regression, regression coefficient and intercept were calculated.

\section{RESULTS}

Table No. 1 shows that mean height of male subjects is $171.99 \pm 6.04$. Mean of length of right and left ulna in male subjects are $26.92 \pm 1.30$ and $26.85 \pm 1.32$ respectively. The mean height of female subjects is $165.49 \pm 3.18$. Mean of length of right and left ulna in female subjects are $21.77 \pm 0.93$ and $21.69 \pm 0.88$ respectively. The mean length of ulna irrespective of side in males and females is $26.89 \pm 1.31$ and $21.73 \pm$ 0.90 respectively.

Table 1: Mean height, length of right and left ulna in Males and Females.

\begin{tabular}{|c|c|c|c|c|c|c|}
\hline \multirow{2}{*}{ Parameter } & \multicolumn{2}{|c|}{ Males } & \multicolumn{2}{c|}{ Females } & \multicolumn{2}{c|}{ Both } \\
\cline { 2 - 7 } & Mean & SD & Mean & SD & Mean & SD \\
\hline Height (cm) & 171.99 & 6.04 & 165.49 & 3.18 & 168.74 & 5.81 \\
\hline Length of Right Ulna & 26.92 & 1.3 & 21.77 & 0.93 & 24.35 & 2.81 \\
\hline Length of Left Ulna & 26.85 & 1.32 & 21.69 & 0.88 & 24.27 & 2.81 \\
\hline $\begin{array}{c}\text { Mean of Right \& left } \\
\text { length of ulna }\end{array}$ & 26.89 & 1.31 & 21.73 & 0.9 & 24.31 & 2.81 \\
\hline
\end{tabular}

Table No. 2 shows that the correlation of stature with ulnar length is 0.66 in males and 0.70 in females, which are positive and statistically highly significant $(P<0.01)$ i.e. if length of ulna increases or decreases, the stature of the subject also increases or decreases and vice versa.

Table 2: Pearson's correlation coefficient.

\begin{tabular}{|c|c|c|}
\hline Sex & $\begin{array}{c}\text { Correlation } \\
\text { coefficient }\end{array}$ & P value \\
\hline Males & 0.6612 & $<0.0001$ \\
\hline Females & 0.7003 & $<0.0001$ \\
\hline Both & 0.7338 & $<0.0001$ \\
\hline
\end{tabular}

Graph 1: Correlation between Length of ulna and Height in Males.

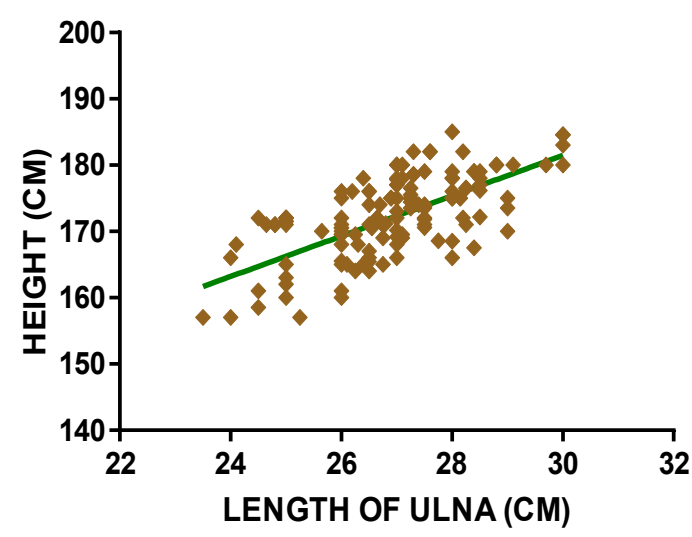


Graph 2: Correlation between Length of ulna and Height in Females.

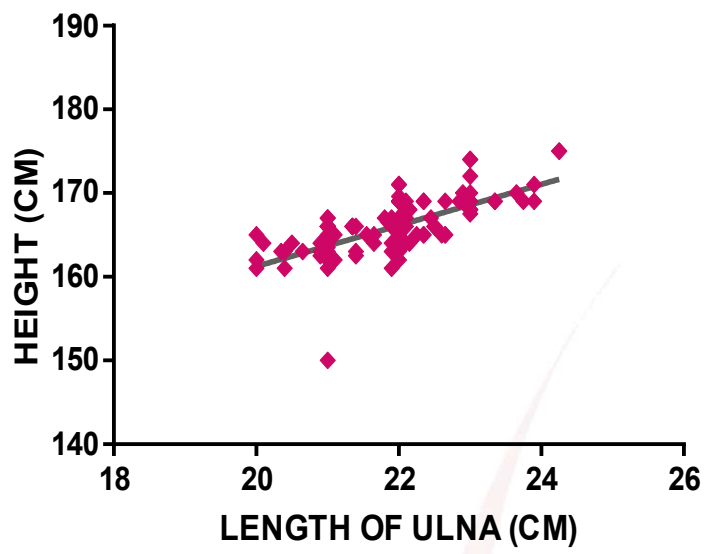

Graph 3: Correlation between Length of ulna and Height irrespective of sex.

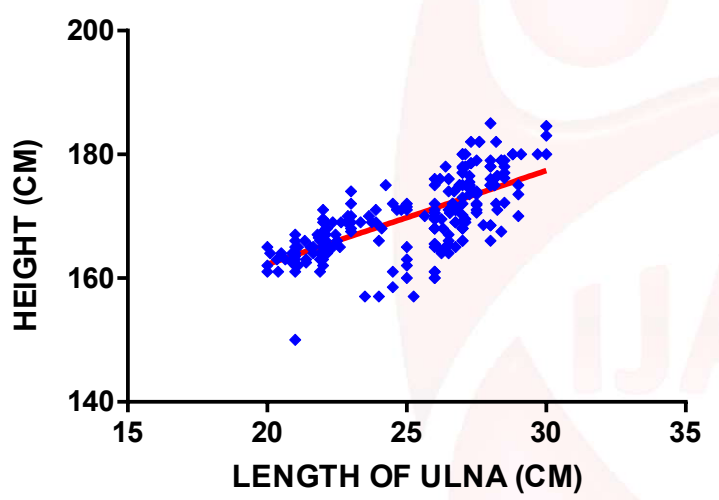

Table No. 3 shows the linear regression equation for stature with ulnar length in male and female where, $Y=$ Height/ Stature $(\mathrm{cm})$, $X=$ Length of ulna $(\mathrm{cm}), 90.15$ and 112.1 are intercept (constant) for male and female. 3.044 and 2.455 are regression coefficient for male and female.From the table below it is seen that the regression formula within a region also varies between male and female population of that region.

Table 3: Regression equation for height with length of ulna.

\begin{tabular}{|c|c|c|}
\hline Sex & Regression Equation & P value \\
\hline Males & $\mathrm{Y}=3.044^{*} \mathrm{X}+90.14$ & $<0.0001$ \\
\hline Females & $\mathrm{Y}=2.455^{*} \mathrm{X}+112.1$ & $<0.0001$ \\
\hline Both & $\mathrm{Y}=1.516^{*} \mathrm{X}+131.9$ & $<0.0001$ \\
\hline
\end{tabular}

\section{DISCUSSION}

In the present study, mean height of subjects is $171.99 \mathrm{~cm}$ in males and $165.49 \mathrm{~cm}$ in females which are comparable with previous studies. The difference between mean height of male and female subject's i.e. gender difference are statistically significant $(P<0.05)$. So the males of a population are taller than females.

From the table No.4 \& 5, it is clear that mean height of subjects within an age group varies within different regions of a country. It may be due to geographical, racial as well as genetic factors or may be due to dietary habits, lifestyle and physical stress. So if the differences in mean height of subjects of different population are due to geographical, racial and genetic factors, we can safely presume that it will remain constant for a long period of time. But if predominate influence is observed to be plastic ones (i.e. dietary habits, lifestyle and physical stress), it is hypothesized that the anthropometric standards will have to be evaluated from time to time in the perspective of such influences for their validity [6].

In present study, mean length of right and left ulna in males and females were $26.92 \mathrm{~cm}$, $26.85 \mathrm{~cm}$ and $21.77 \mathrm{~cm}, 21.69 \mathrm{~cm}$ respectively. The difference between mean ulnar length of male and female subjects i.e. gender difference is statistically significant $(P<0.05)$ which coincides with that of previous studies.

Table 4: Comparison of mean of total height and mean of length of ulna in Males.

\begin{tabular}{|c|c|c|c|c|c|}
\hline \multirow{2}{*}{ Author } & \multirow{2}{*}{ Year } & \multirow{2}{*}{ Region } & \multirow{2}{*}{$\begin{array}{c}\text { Mean } \\
\text { Height }(\mathrm{cm})\end{array}$} & \multicolumn{2}{|c|}{$\begin{array}{c}\text { Mean length of } \\
\text { Ulna (cm) }\end{array}$} \\
\cline { 5 - 7 } & & & & Right & Left \\
\hline Anjali Prasad [3] & 2012 & Marathada & 171.93 & 26.92 & 26.86 \\
\hline Avantika Bamne [7] & 2014 & Maharashtra & 172.31 & 27.9 & 27.75 \\
\hline A Anupriya [2] & 2016 & Tamilnadu & 164.4 & 27.7 & 27.6 \\
\hline Acharya Veena Anand [8] & 2016 & Gulbarga & 172.13 & 28.1 & 27.69 \\
\hline Anjali Krishna Prasad [6] & 2016 & MP & 172.93 & 27.52 & 27.26 \\
\hline Ashish Pandey [9] & 2016 & Bangalore & 169.46 & 27.52 & 27.62 \\
\hline Chintala Durga Sukumar [10] & 2017 & Vijaywada & 165.72 & 29.84 & 29.78 \\
\hline Martula Lemtur [11] & 2017 & Nagaland & 168.12 & 27.45 & 27.42 \\
\hline Present Study & 2018 & Marathwada & 171.99 & 26.92 & 26.85 \\
\hline
\end{tabular}

From Table No. 6 \& 7 it is observed that all workers got positive correlation between stature and length of ulna indicating strong relation between the two parameters.

Regression formulae is population specific and sex specific due to genetic differences, isolation differences, differences in bio-cultural history and other factors. The researchers determined that the stature estimation formulae should be recalculated within appropriate time intervals, even for same racial Populations [12]. 
Table 5: Comparison of mean of height and mean of length of ulna in Females.

\begin{tabular}{|c|c|c|c|c|c|}
\hline \multirow{2}{*}{ Author } & Year & Region & $\begin{array}{c}\text { Mean } \\
\text { Height (cm) }\end{array}$ & $\begin{array}{c}\text { Mean length of } \\
\text { Ulna (cm) }\end{array}$ \\
\cline { 5 - 6 } & & & & Right & Left \\
\hline Anjali Prasad [3] & 2012 & Marathada & 165.43 & 21.75 & 21.68 \\
\hline Avantika Bamne [7] & 2014 & Maharashtra & 172.31 & 27.9 & 27.75 \\
\hline A Anupriya [2] & 2016 & Tamilnadu & 153.7 & 25.6 & 25.4 \\
\hline Acharya Veena Anand [8] & 2016 & Gulbarga & 157.28 & 25.48 & 25.05 \\
\hline Anjali Krishna Prasad [6] & 2016 & MP & 166.53 & 21.75 & 21.68 \\
\hline Ashish Pandey [9] & 2016 & Bangalore & 164.07 & 26.22 & 26.22 \\
\hline Chintala Durga Sukumar [10] & 2017 & Vijaywada & 160.58 & 26.7 & 26.63 \\
\hline Martula Lemtur [11] & 2017 & Nagaland & 157 & 25.15 & 21.1 \\
\hline Present Study & 2018 & Marathwada & 165.49 & 21.77 & 21.69 \\
\hline
\end{tabular}

Table 6: Comparison of Regression equation in Males.

\begin{tabular}{|c|c|c|c|c|}
\hline \multirow{2}{*}{ Author } & \multirow{2}{*}{ Year } & \multirow{2}{*}{ Region } & \multicolumn{2}{|c|}{ Regression Equation } \\
\cline { 4 - 5 } & & & Right & Left \\
\hline Anjali Krishna Prasad [3] & 2012 & Marathwada & \multicolumn{2}{|c|}{$\mathrm{Y}=93.45+2.92 \mathrm{X}$} \\
\hline Avantika Bamne [7] & 2014 & Maharashtra & $\mathrm{Y}=65.77+3.81 \mathrm{X}$ & $\mathrm{Y}=64.17+3.89 \mathrm{X}$ \\
\hline A Anupriya [2] & 2016 & Tamilnadu & $\mathrm{Y}=63.984+3.631 \mathrm{X}$ & $\mathrm{Y}=66.232+3.551 \mathrm{X}$ \\
\hline Acharya Veena Anand [8] & 2016 & Gulbarga & $\mathrm{Y}=69.4+3.65 \mathrm{X}$ & $\mathrm{Y}=64.1+3.90 \mathrm{X}$ \\
\hline Anjali Krishna Prasad [6] & 2016 & $\mathrm{MP}$ & \multicolumn{2}{|c|}{$\mathrm{Y}=93.45+2.92 \mathrm{X}$} \\
\hline Chintala D. Sukumar [10] & 2017 & Vijaywada & $\mathrm{Y}=111.8+1.80 \mathrm{X}$ & $\mathrm{Y}=112.13+1.79 \mathrm{X}$ \\
\hline Balkrishna Thummar [14] & 2011 & Gujrat & $\mathrm{Y}=81.11+3.117 \mathrm{X}$ & $\mathrm{Y}=65.76+3.667 \mathrm{X}$ \\
\hline Martula Lemtur [11] & 2017 & Nagaland & \multicolumn{2}{|c|}{$\mathrm{Y}=84.34+3.05 \mathrm{X}$} \\
\hline Present Study & 2018 & Marathwada & $\mathrm{Y}=90.14+3.044 \mathrm{X}$ \\
\hline
\end{tabular}

Table 7: Comparison of Regression Equation in Females.

\begin{tabular}{|c|c|c|c|c|}
\hline \multirow{2}{*}{ Author } & \multirow{2}{*}{ Year } & \multirow{2}{*}{ Region } & \multicolumn{2}{|c|}{ Regression Equation } \\
\cline { 4 - 5 } & & & Right & Left \\
\hline Anjali Krishna Prasad [3] & 2012 & Marathwada & \multicolumn{2}{|c|}{$\mathrm{Y}=113.89+2.37 \mathrm{X}$} \\
\hline Avantika Bamne [7] & 2014 & Maharashtra & $\mathrm{Y}=70.75+3.46 \mathrm{X}$ & $\mathrm{Y}=102.82+2.21 \mathrm{X}$ \\
\hline A Anupriya [2] & 2016 & Tamilnadu & $\mathrm{Y}=57.995+3.745 \mathrm{X}$ & $\mathrm{Y}=56.048+3.839 \mathrm{X}$ \\
\hline Acharya Veena Anand [8] & 2016 & Gulbarga & $\mathrm{Y}=80.2+3.03 \mathrm{X}$ & $\mathrm{Y}=74.0+3.33 \mathrm{X}$ \\
\hline Anjali Krishna Prasad [6] & 2016 & $\mathrm{MP}$ & \multicolumn{2}{|c|}{$\mathrm{Y}=113.89+2.37 \mathrm{X}$} \\
\hline Chintala D. Sukumar [10] & 2017 & Vijaywada & $\mathrm{Y}=57.16+3.87 \mathrm{X}$ & $\mathrm{Y}=47.05+4.23 \mathrm{X}$ \\
\hline Balkrishna Thummar [14] & 2011 & Gujrat & $\mathrm{Y}=17.10+5.314 \mathrm{X}$ & $\mathrm{Y}=18.95+5.335 \mathrm{X}$ \\
\hline Martula Lemtur [11] & 2017 & Nagaland & \multicolumn{2}{|c|}{$\mathrm{Y}=74.83+3.29 \mathrm{X}$} \\
\hline Present Study & 2018 & Marathwada & $\mathrm{Y}=112.1+2.455 \mathrm{X}$ \\
\hline
\end{tabular}

Body ratios within specific population groups also changes over time due to changes in diet, lifestyle and socio- economic status, and therefore the present regression formulae may need readjustment [12].

Furthermore, racial variation in the relationship between ulna length and height has been clearly demonstrated by comparative studies between Black, White and Asian subjects [13].
The present study further highlights the racial diversity in mean ulna length.

\section{CONCLUSION}

Mean height and length of ulna is more in males than in females and it is statistically significant. There is positive correlation between stature and length of ulna. Simple linear regression equation so far derived can be used if either of the 
measurement of length of ulna or total height is known, the other can be calculated. This fact will be of practical use in Medico Legal investigations and in Anthropometry. Study would be useful for Anthropologist and Forensic Medicine experts.

\section{Conflicts of Interests: None}

\section{REFERENCES}

[1]. Gaur R, Kaur K, Airi R, Jarodia K. Estimation of Stature from Percutaneous Lengths of Tibia and Fibula of Scheduled Castes of Haryana State, India. Ann Forensic Res Anal 2016;3(1):1025.

[2]. Anupriya A, Kalpana R. Estimating the Height of an Individual from the Length of Ulna in Tamil Nadu Population and its Clinical Significance. Int J Sci Stud 2016;4(1):254-257.

[3]. Anjali Prasad et.al Estimation of Human Stature from length of ulna in Marathwada Region of Maharashtra Int J Biol Med Res. 2012;3(4):23372341.

[4]. Martin R. Lehrbuch der Anthropologie. In: Lawrence H. Bannister, Martin M. Berry, Patricia Collins, Mary Dyson, Julian E. Deusek, Mark W. J. Ferguson, editor. Gray s Anatomy- Anatomical Basis of Medicine and Surgery 38th edition; London: Churchill Livingstone; 1999.

[5]. Vallois HV. Anthropometric techniques. Curr Anthropol 1965;6:127-44. Cited in: Krishan K, Sharma A. Estimation of stature from dimensions of hands and feet in a North Indian population. J Forensic Leg Med 2007;14: 327-32.
[6]. Anjali Krishna Prasad et al. Estimation of human stature from ulnar length in rural region of Maharashtra Indian Journal of Clinical Anatomy and Physiology, July-September 2016;3(3);343-347.

[7]. Bamne A, Bamne SN, Choursia RS, Gohiya VK. Estimation of stature from length of ulna in Maharashtrian population. Int J Med Sci Public Health2015;4:65-69.

[8]. Acharya Veena Anand et al. Stature estimation measuring percutaneous length of ulna in living subjects Indian Journal of Clinical Anatomy and Physiology, July-September 2016;3(3);270-275.

[9]. Ashish Pandey, Radhika P.M, Shailaja Shetty. Estimation Of Human Stature From Length Of Ulna In Indian Population. Int J Anat Res 2017;5(1):33503353. DOI: 10.16965/ijar.2016.473.

[10]. Chintala Durga Sukumar., Estimation of Stature based on percutaneous length of Ulna in living subjects. Sch. J. App. Med. Sci., May 2017; 5(5C):1897-1902.

[11]. Martula Lemtur et al Estimation of Stature from Percutaneous Length of Ulna and Tibia in Medical Students of Nagaland IOSR Journal of Dental and Medical Sciences. 2017;16(Ver. VII):46-52.

[12]. Dayal MR, Steyn M, Kuykendall KL. Stature estimation from bones of South African whites. South African Journal of Science 2008 April;104:124-128.

[13]. Illayperuma I, Nanayakkara G. Palahepitiya N. A Model for the Estimation of Personal Stature from Length of Forearm. Int. J. Morphol. 2010;28(4):10811086.

[14]. Dr.Balkrishna Thummar et al. Measurement of UInar Length for estimation of Stature in Gujarat, NJIRM 2011; Vol. 2(2).April-June-Special: 36-40.

How to cite this article:

Vaishali Inamdar, Syed Imran Sultan. ESTIMATION OF STATURE FROM PERCUTANEOUS LENGTH OF ULNA IN LIVING SUBJECTS IN MARATHWADA REGION OF MAHARASHTRA. Int J Anat Res 2018;6(2.2):5213-5217. DOI: 10.16965/ijar.2018.159 